\title{
Effects of Spartina alterniflora invasion on benthic nematode communities in the Yangtze Estuary
}

\author{
Huili Chen, Bo Li, Jianbo Hu, Jiakuan Chen, Jihua Wu* \\ Ministry of Education Key Laboratory for Biodiversity Science and Ecological Engineering, Institute of Biodiversity Science, \\ Fudan University, Shanghai 200433, PR China
}

\begin{abstract}
Invasions of exotic plant species in estuaries have occurred worldwide, and may profoundly affect native biodiversity and estuarine ecosystem functioning. To assess the effect of plant invasions on benthic meiofauna, we compared the nematode communities in marshes dominated, respectively, by invasive Spartina alterniflora and native Scirpus mariqueter and Phragmites australis at 3 local sites over 2 seasons in the Yangtze River estuary, PR China. S. alterniflora stands had generally lower nematode trophic diversity than the stands of the 2 native plants, suggesting that the exotic plant led to a simplified benthic food web. The relative abundance of bacterial-feeding nematodes tended to increase in $S$. alterniflora marshes compared to $P$. australis marshes. The increased bacterial-feeding nematodes in $S$. alterniflora stands are likely to reflect the altered decomposition processes, rates and pathways, which may, in turn, modify belowground nutrient cycling of the estuarine ecosystems. The dissimilarity in nematode community structure between $S$. alterniflora and $S$. mariqueter marshes was smaller than that between $S$. alterniflora and $P$. australis marshes, and the dissimilarity between Spartina-invaded and native marshes was even smaller than between the 2 native plant marshes. It is suggested that the detection of the ecological consequences of plant invasions depends on which native plant species is considered. Site effects were generally detected in the comparison of sediment properties and nematodes among 3 plant marshes. Sediment water content, electrical conductivity, bacterial biomass and litter biomass were identified as the most important factors in the shaping of the nematode communities.
\end{abstract}

KEY WORDS: Community structure $\cdot$ Cordgrass $\cdot \mathrm{C}_{3}$ plant $\cdot \mathrm{C}_{4}$ plant $\cdot$ Diversity $\cdot$ Exotic plant $\cdot$ Nematodes $\cdot$ Wetlands

Resale or republication not permitted without written consent of the publisher

\section{INTRODUCTION}

Estuaries are widely recognized as an important ecosystem type for a wide range of marine communities, and play major roles in conserving biodiversity (Levin et al. 2001). However, they are undergoing rapid environmental changes caused by anthropogenic activities, including eutrophication, non-nutrient pollutants, overfishing, habitat alteration, global climate, and species invasions (Levin et al. 1996, Jackson et al. 2001). Compared with other ecosystems, estuaries have become one of the most heavily invaded ecosystems in the world (Cohen \& Carlton 1998, Grosholz 2002). Invasions of exotic plant species in the estuaries have occurred worldwide (Ruiz et al. 1997), and may profoundly affect native biodiversity and estuarine ecosystem functioning (Posey 1988, Posey et al. 1993, Talley \& Levin 2001, Cheng et al. 2006).

Cordgrasses (plants in the genus Spartina Schreb.) are successful invaders in coastal wetlands and have spread across the globe (Chen et al. 2004, Levin et al. 2006). S. alterniflora has caused considerable evolutionary and ecological consequences to global estuaries (Wang et al. 2006). It originated on the east and gulf coasts of the USA and spread to many coastal and estuarine regions of the world, including tidal marshes on the west coast of North America, as well as in Australia, France, The Netherlands, UK, New Zealand and China (Kriwoken \& Hedge 2000, Neira et al. 2005). Many previous studies have reported that 
Spartina invasions influence benthic communities when compared with unvegetated mudflats (Zipperer 1996, O'Connell 2002, Neira et al. 2005), and several studies have compared benthic macrofaunal communities of the invasive Spartina and those of native vegetated marshes (Hedge \& Kriwoken 2000, Chen et al. 2005, Neira et al. 2005), and yielded inconsistent results. In Little Swanport estuary, Tasmania, Hedge \& Kriwoken (2000) found that species richness and total abundance of macrofauna in invasive $S$. anglica and native saltmarshes do not differ significantly. Chen et al. (2005) reported that the replacement of Scirpus mariqueter by $S$. alterniflora results in reduced macroinvertebrate density and species diversity in salt marshes of Chongming Island in the Yangtze River estuary, China. Neira et al. (2005) found higher macrofaunal species richness in Spartina hybrid-invaded patches relative to native Salicornia marshes in San Francisco Bay, USA, but no differences in total macrofaunal density were found. These studies suggest that the responses of benthic macrofauna to Spartina spp. invasions are quite variable, depending on the vegetation type and invaded sites (Neira et al. 2005). However, knowledge is lacking about the impacts of Spartina invasions on benthic meiofaunal communities such as nematodes.

In the present study, we compared the benthic nematode communities of Spartina alterniflora-invaded marshes and 2 native plant marshes (Scirpus mariqueter and Phragmites australis) at 3 local sites over 2 seasons in the Yangtze River estuary, China. S. alterniflora was intentionally introduced into the Yangtze River estuary to promote sediment accretion and growth of salt marshes in the late 1980s, as it has a number of biological traits promoting that goal, including fast growth, dense rhizomal network, and great biomass. This species spread to most of the wetlands in the Yangtze River estuary and is now excluding native plant species by forming dense monocultures.

Nematodes were selected to evaluate the effects of plant invasion in this study, because they have close relationships with vegetations (Ingham et al. 1985, Yeates 1999). In addition, they are the most abundant metazoan taxon, comprising 60 to $90 \%$ of the total fauna in estuarine sediments (Coull 1999). They play a central role in the detrital food web (Moore \& de Ruiter 1991) and are assumed to function as regulators of decomposition and mineralization processes (Coleman 1985). Thus, nematode communities can provide unique insights into many aspects of ecosystem processes and have been increasingly used as bioindicators of ecosystem functioning (Ritz \& Trudgill 1999, Wu et al. 2002). In the present study, we analyzed the density, diversity, community structure, and trophic composition of benthic nematodes, and related the various sediment properties and vegetation characteristics to nematode communities. The specific objectives of the study were: (1) to compare the nematode communities between the invasive Spartina alterniflora and the native plant marshes and (2) to increase our limited knowledge of the effects of plant invasions on benthic nematodes in estuarine ecosystems.

\section{MATERIALS AND METHODS}

Study sites. The study was carried out in the tidal marshes of the Yangtze River estuary, PR China. Tidal marshes from 3 sites in the estuary were chosen for study: Dongtan of Chongming Island, Jiuduansha Islands, and Nanhui (Fig. 1). At these sites, Scirpus mariqueter (hereafter Scirpus) and Phragmites australis (hereafter Phragmites) were the most common marsh plant species; both are $\mathrm{C}_{3}$ plants and native to the Yangtze River estuary. Scirpus occurs in middle and high marshes, and Phragmites in high marshes (Gao \& Zhang 2006). Since the tidal marshes in the study area are now heavily infested with introduced $\mathrm{C}_{4}$ plant Spartina alterniflora (hereafter Spartina), the 2 native plant species are rapidly being replaced by this exotic plant. Spartina expands its range mainly by colonizing the high marsh zones, but also by extending to the middle marshes.

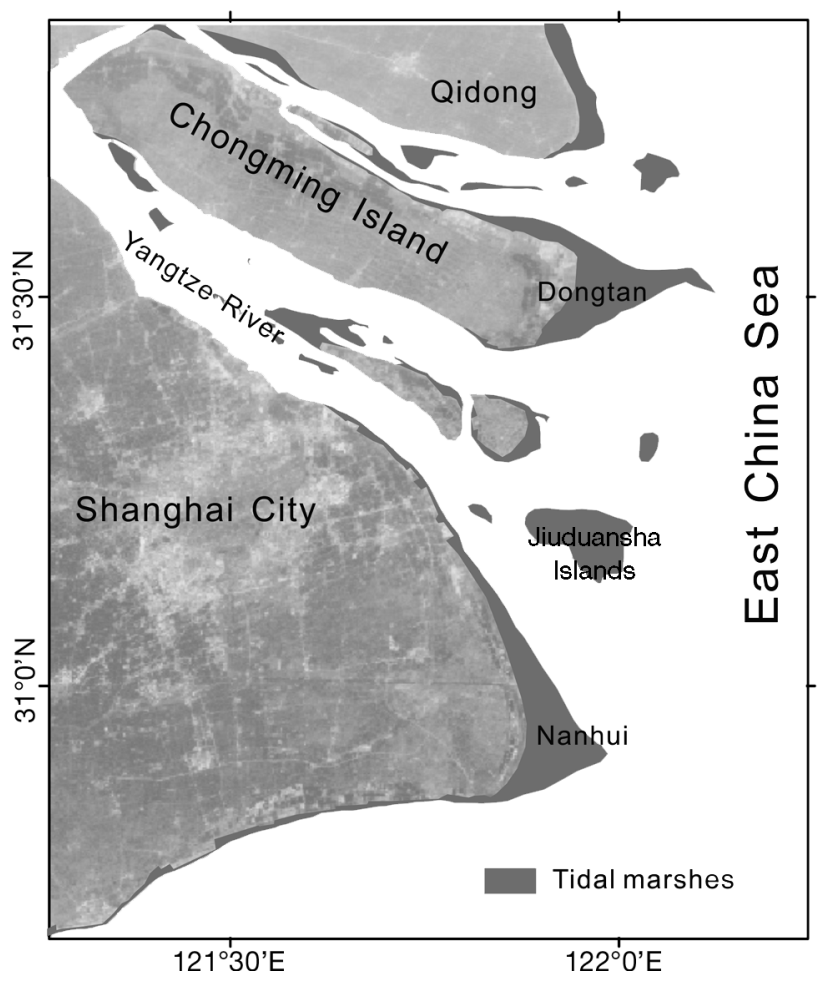

Fig. 1. Location of 3 sampling sites (Dongtan, Jiuduansha, and Nanhui) in the Yangtze River estuary, PR China 
In Dongtan marshes, small Spartina patches were first found in 1995. Spartina was intentionally introduced to Jiuduansha in 1997, to attract shorebirds away from flightpaths in and out of Pudong Airport. Both Dongtan and Jiuduansha are national nature reserves. Comparatively, Nanhui received more disturbance than the other 2 sites. In Nanhui marshes, Spartina was first transplanted to promote sediment accretion in the late 1980s. At each study site, 3 meadows at more-orless similar tidal elevations were selected for sampling in the tidal marshes dominated by Spartina, Scirpus, and Phragmites, respectively. A global positioning system (GPS) was used to ensure the consistency of sampling location in different sampling seasons.

Sampling design and environmental conditions. Samplings were carried out in March and August 2004. Sediment samples were collected using a modified O'Connor split corer $(3.2 \mathrm{~cm}$ diameter, $10 \mathrm{~cm}$ depth). In each meadow, 4 transects of $20 \mathrm{~m}$ in length parallel to the coastline were established with a random starting point. Ten sediment cores taken at $2 \mathrm{~m}$ intervals along each transect were bulked into a single composite sample to reduce variance associated with the aggregated spatial pattern of benthic nematodes. Thus, 4 composite samples were obtained at each meadow as 4 independent replicates. Each of the composite sediment samples was well homogenized by hand and then split into 4 parts: $150 \mathrm{~g}$ of sediment were fixed in $4 \%$ formalin for nematode community analysis, $50 \mathrm{~g}$ of sediment were used for measurement of bacterial biomass, $100 \mathrm{~g}$ were dried to constant weight at $80^{\circ} \mathrm{C}$ to determine water content, and the rest of each sub-sample was air-dried and analyzed for physical and chemical properties, including organic matter, $\mathrm{pH}$, electrical conductivity, total nitrogen, total phosphorus (measured at the Institute of Soil Science, Chinese Academy of Sciences), and sediment grain composition (measured at the Cold and Arid Environmental and Engineering Research Institute, Chinese Academy of Sciences). The biomass of sedimentary bacteria was determined by counting bacteria stained with fluoroscein isothiocyanate (FITC) by direct microscopic observation (Babiuk \& Paul 1970). Standing shoots of plants were harvested in two $25 \times 25 \mathrm{~cm}$ quadrats along each transect, for the determination of shoot biomass. Surface litter within the quadrat was also collected for the determination of litter biomass. There were no standing shoots of Scirpus in March and no surface litter of Scirpus in August.

Nematodes. Nematodes were extracted by flotation in Ludox TM in the laboratory (Griffiths et al. 1990). After counting the total numbers of nematodes under a dissecting microscope, about 100 nematode specimens per sample were randomly selected and identified to genus level in glycerol mounts.
Nematodes were assigned to 6 trophic groups (algal feeder, plant feeder, bacterial feeder, fungal feeder, carnivore, and omnivore) according to Yeates et al. (1993). Several ecological indices were calculated to assess the nematode community. The Shannon-Wiener diversity index $\left(H^{\prime}\right)$ was calculated at the genus level. The trophic diversity index (TD) was calculated based on the trophic group ratios.

Statistical analysis. The effects of plant type, site, and sampling time on nematodes, sediment properties, and plant characteristics were examined using a 3-way factorial ANOVA. Least-square-difference (LSD) tests were used after the 3-way ANOVA to detect for the differences in environmental variables, nematode genus number, density, Shannon-Wiener diversity index, trophic diversity index, and feeding group proportions between the marshes dominated by different plant species at each site in March and August, respectively. To meet the assumptions of ANOVA, the proportional data were arcsine-square-root transformed and the numeric data were log transformed prior to statistical analyses when necessary. All analyses were executed using the statistical package Statistica (Version 6.0, StatSoft).

All multivariate analyses were undertaken using the PRIMER (Version 5.2) software package (Clarke \& Warwick 1994). Using a ranked similarity matrix based on Bray-Curtis similarity measures of $\log (x+1)$ transformed nematode genera data, an ordination plot was produced by non-metric multidimensional scaling (MDS). The 2-way crossed analysis of similarity (ANOSIM) (Clarke \& Warwick 1994) was used to test vegetation and site effects on the nematode community. The BIO-ENV procedure (Clarke \& Ainsworth 1993) was used to identify the environmental variables that best explained variation in nematode communities at the genus level and the functional group level, respectively. BIO-ENV uses Spearman's rank correlation between the resulting ranked similarity matrices of nematofauna and correlation-based PCA (principal component analysis) of the normalized environmental variables.

\section{RESULTS}

The magnitude or directions of differences in most sediment conditions between Spartina and 2 native plant marshes varied among the 3 sites and between 2 sampling seasons (Table 1). Most sediment properties were significantly different between Spartina and the 2 native plant marshes, except at Jiuduansha in August (Table 1). In March, Spartina generally had greater shoot biomass, but lower litter biomass than both Phragmites and Scirpus, and the magnitude of the 


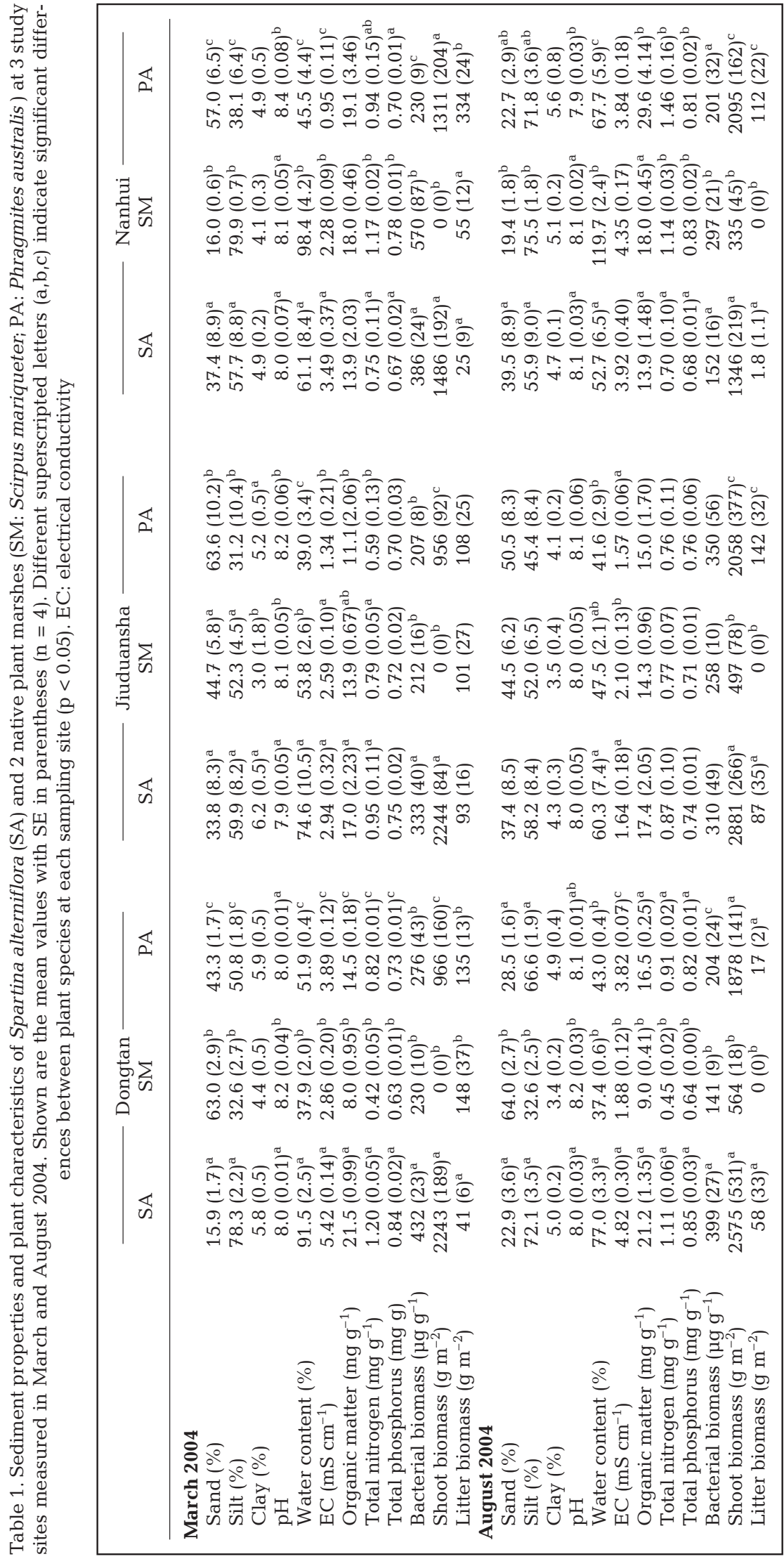

differences varied across sites. In August, Spartina had greater shoot and litter biomass than Scirpus, but the differences in shoot and litter biomass between Spartina and Phragmites were not consistent at different sites. A 3way ANOVA shows that all parameters for sediment properties and plant characteristics significantly differed among 3 marsh types (Table 2). Except for the percent clay content, all other parameters were significantly affected both by an interactive effect between time and plant and by an interactive effect between site and plant (Table 2).

A total of 59 nematode genera were identified in our study, more than half of which were bacterial feeders (Table 3). Nematode generic richness, density, values of $H^{\prime}$, and TD indices were significantly affected by the plant species (Table 4), and were also significantly affected by an interactive effect between site and plant. All feeding groups were affected by plant type, except for algal feeders (Table 4). The interactions between plant type and site were significant for all nematode feeding groups (Table 4).

No significant difference was observed in nematode genus number between Spartina-invaded and Phragmites marshes at any site in the 2 sampling seasons (Fig. 2a). At Dongtan and Jiuduansha, the differences in genus number between Spartina and Scirpus marshes varied with seasons. At Nanhui, Spartina-invaded marshes had lower nematode genus number than Scirpus marshes in both seasons. Total nematode density was significantly higher in Spartina-invaded marshes than in the 2 native plant marshes at Dongtan, but not at Jiuduansha and Nanhui (Fig. 2b). No significant differences in Shannon-Wiener diversity index were found between Spartinainvaded and Phragmites marshes, except at Jiuduansha in August (Fig. 2c). Scirpus marshes had significantly lower Shannon-Wiener diversity than Spartina-invaded marshes at Nanhui in both seasons. At Dongtan and Jiuduansha, the differences in Shannon-Wiener diversity between Spartina 


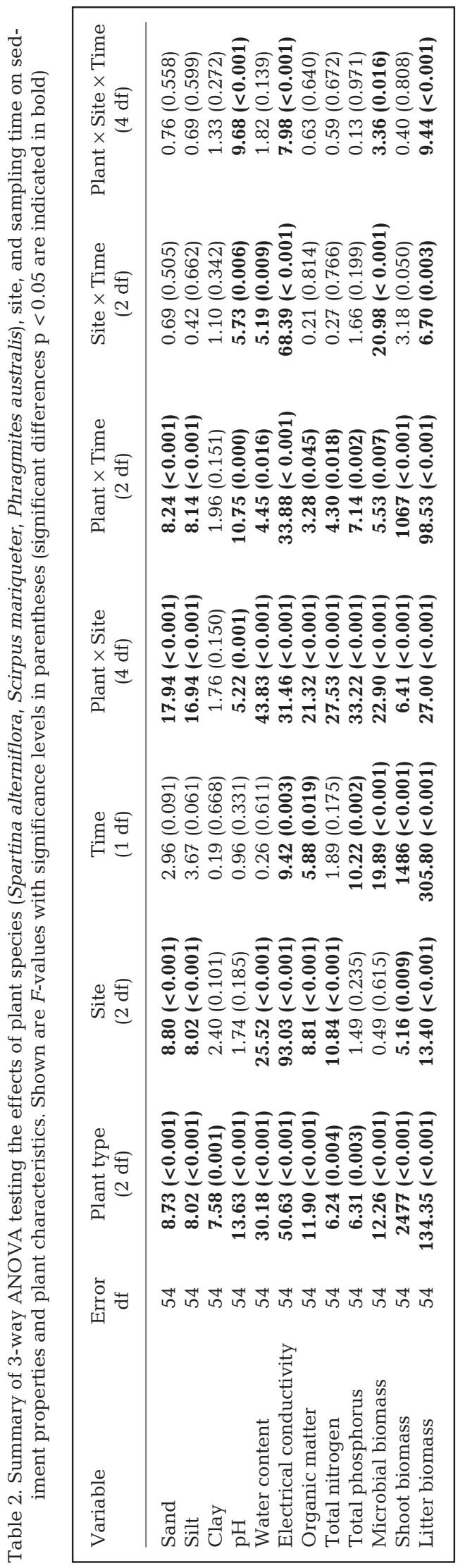

and Scirpus marshes varied with seasons. Spartina-invaded marshes had lower nematode trophic diversity than Phragmites marshes in all comparisons, with significant differences occurring at Dongtan in August, at Jiuduansha in March, and at Nanhui in both seasons (Fig. 2d). Spartina marshes had significantly lower nematode trophic diversity than Scirpus marshes at Dongtan in both seasons and at Jiuduansha in March, while no significant differences were observed in other cases.

The dominant trophic groups were bacterial feeders and algal feeders for all types of marshes (Fig. 3). Percentages of algal feeders (Fig. 3a) exhibited significant differences among plant species at Dongtan and Nanhui, while inconsistent differences between Spartina and the 2 native marshes were observed across sites and seasons. In most comparisons, the relative abundance of plant feeders (Fig. 3b) and fungal feeders (Fig. 3c) in Spartina marshes was generally similar to that in Scirpus marshes, but lower than that in Phragmites marshes. In terms of the bacterial feeders (Fig. 3d), Spartina marshes tended to have more bacterial feeders than Phragmites marshes at all sites and in both seasons, with significant differences occurring at Dongtan and Jiuduansha in both seasons and at Nanhui in March. Spartina marshes also had more bacterial feeders than Scirpus marshes, except at Nanhui in August. The percentages of carnivores (Fig. 3e) and omnivores (Fig. 3f) exhibited inconsistent trends among different types of vegetation across sites and between seasons.

Two-way crossed ANOSIM revealed highly significant plant (Global test: $R=0.748, \mathrm{p}=0.001$ ) and site effects (Global test: $R=0.830, \mathrm{p}=0.001$ ) on nematode communities (Table 5). The dissimilarities in nematode communities were smaller between Spartina and Scirpus marshes (ANOSIM, pairwise test: $R=0.679, \mathrm{p}=$ 0.001) than between Spartina and Phragmites marshes (ANOSIM, pairwise test: $R=0.790, \mathrm{p}=0.001$ ). The non-metric MDS analyses show that all plots for Spartina were completely separated from those for Phragmites marshes, but partly overlapped with those for Scirpus marshes (Fig. 4). The greatest dissimilarities of nematode communities among pairs of plants were found between 2 naturally vegetated marshes (ANOSIM, pairwise test: $R=0.852, \mathrm{p}=0.001$ ). The nematode community dissimilarity among pairs of sites was the smallest between Dongtan and Jiuduansha (ANOSIM, pairwise test: $R=0.731, \mathrm{p}=0.001$ ).

BIO-ENV analysis was conducted at both the genus level and the functional group level (Table 6). The correlation coefficients of the best single environmental variable and combinational variables were generally low (coefficients $<0.25$ ). Water content, electrical conductivity, bacterial biomass, and litter biomass were correlated with nematode composition in the analysis 
Table 3. Benthic nematodes in Spartina alterniflora (SA) and 2 native marshes (SM: Scirpus mariqueter; PA: Phragmites australis) sampled in March and August 2004. Shown are the mean values (expressed as individuals per $10 \mathrm{~g}$ dry sediment) with SE in parentheses $(\mathrm{n}=12)$

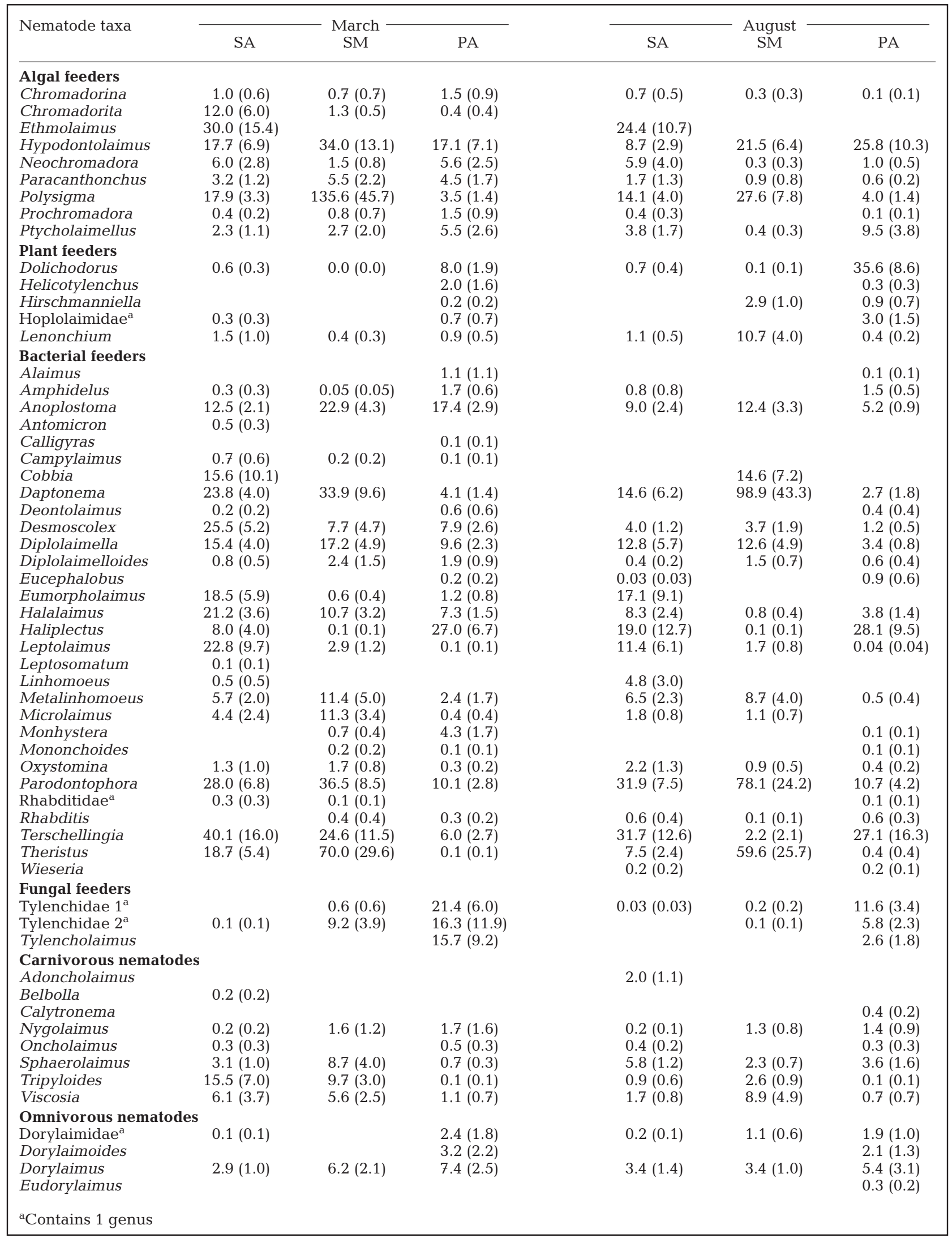




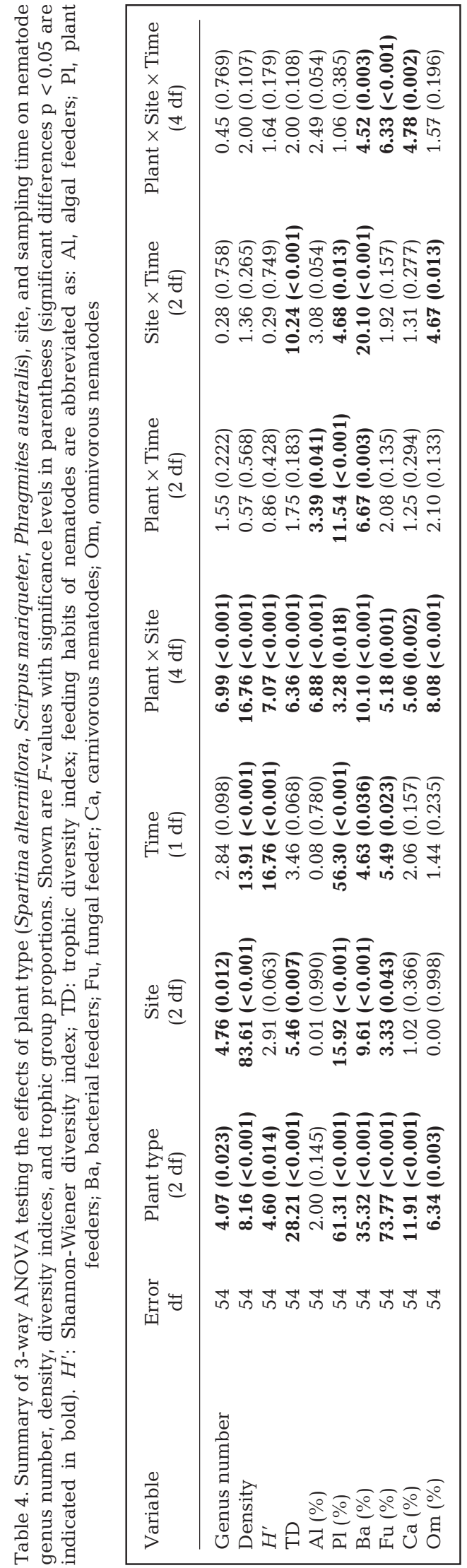

both at the genus level and the functional group level. The silt percentage of the sediment was only correlated with the nematode community at the functional group level. When the analysis was restricted to the single best variable, water content was the most influential variable.

\section{DISCUSSION}

\section{Nematode communities as affected by plant species}

In the present study, we found no significant differences in nematode generic richness or in ShannonWiener diversity between Spartina-invaded and Phragmites marshes. This is consistent with the study of Yuhas et al. (2005), in which Spartina and Phragmites marshes were found to support similar taxon richness of benthic fauna (both macrofauna and meiofauna). However, our results are inconsistent with those of Angradi et al. (2001), who found that the taxon richness of macroinvertebrates is greater in Spartina marshes than in Phragmites-invaded marshes in southern New Jersey. Gratton \& Denno (2005) found that the changes in arthropod trophic structure after the replacement of Spartina by Phragmites are mainly caused by the changes in detritivores, herbivores, and carnivores. In this study, Spartina-invaded marshes generally had lower nematode trophic diversity than Phragmites marshes, with bacterivores tending to be more common. The nematode community structure was found to be distinctly different in Spartina versus Phragmites marshes, as revealed by MDS and ANOSIM analyses. Such differences in community composition have also been found for microbial communities (Ravit et al. 2003) and arthropod communities (Gratton \& Denno 2005) on salt marshes in New Jersey, where Phragmites is an invader. Therefore, it can be speculated that the invasion of Spartina and Phragmites into each other affects both aboveground and belowground ecosystem processes.

Few studies have compared faunal communities between Spartina and Scirpus. One recent study, conducted at Dongtan of Chongming Island, shows that the macroinvertebrate species richness and diversity tends to be lower in the Spartina community than in the Scirpus community (Chen et al. 2005). This pattern was not observed for nematode generic richness and diversity. Chen et al. (2005) found that invasions of Spartina into the Scirpus community alter the trophic group structure of macroinvertebrates. However, the differences in nematode trophic group proportions between Spartina and Scirpus marshes gen- 

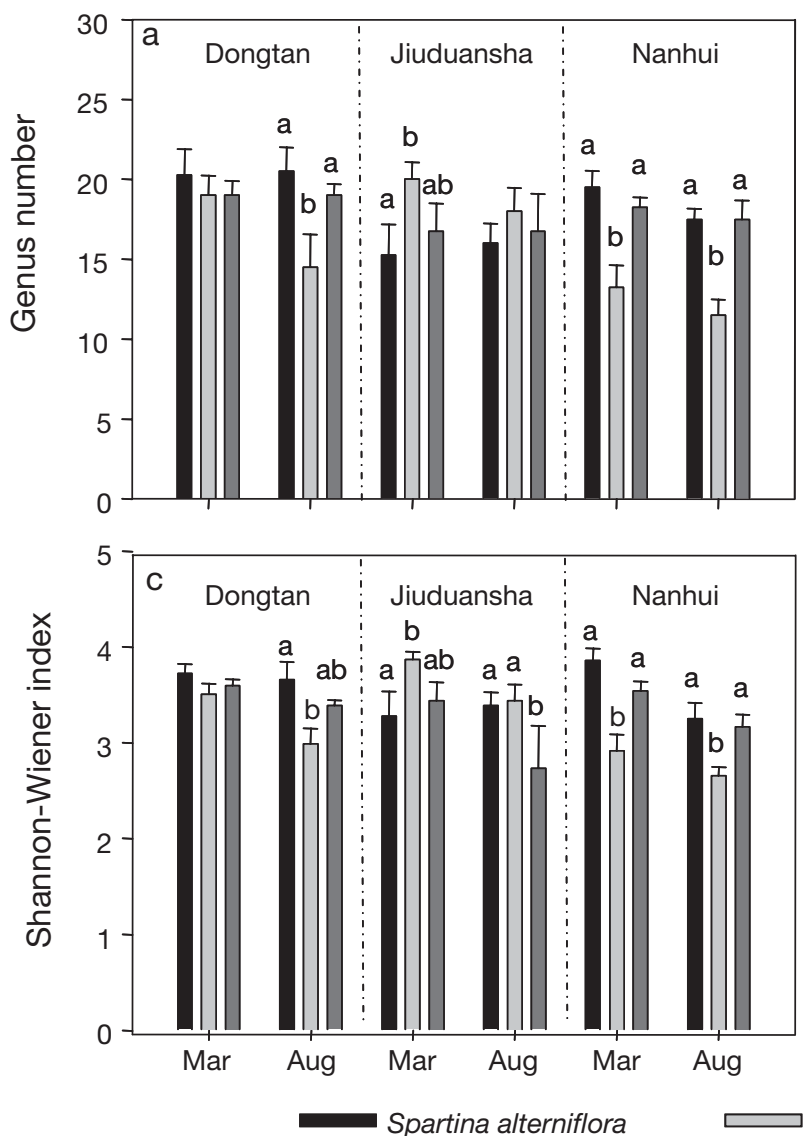
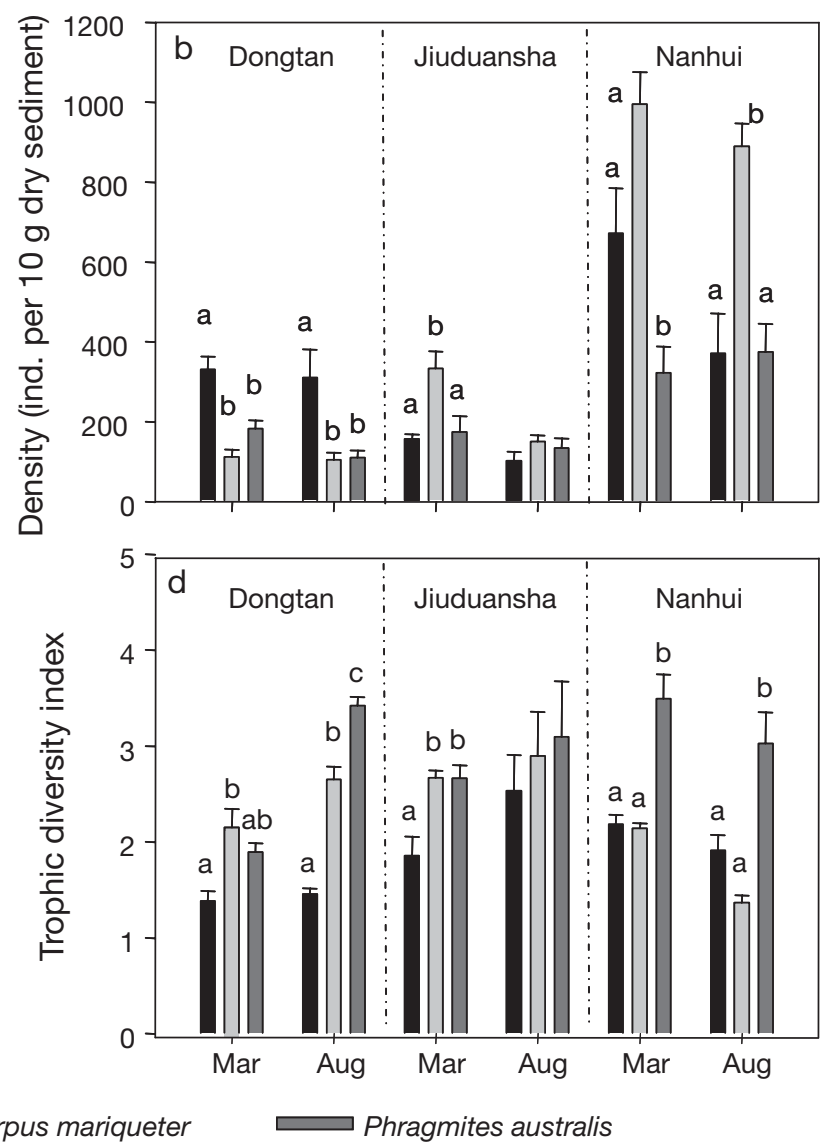

Fig. 2. (a) Nematode genus number, (b) nematode density, (c) Shannon-Wiener diversity index, and (d) trophic diversity index in the 3 marshes dominated respectively by Spartina alterniflora, Scirpus mariqueter, and Phragmites australis at 3 sites in March and August 2004. Error bars indicate standard error of the mean $(n=4)$. Different letters above bars $(a, b, c)$ indicate significant differences between plant species at each sampling site and in each season $(p<0.05)$

Table 5. Two-way crossed ANOSIM for testing the vegetation and site effects on nematode communities, and the differences in nematode communities between plants and between sampling sites. SA: Spartina alterniflora; SM: Scirpus mariqueter; PA: Phragmites australis

\begin{tabular}{|lccc|}
\hline & $\begin{array}{c}\text { Global } \\
\text { test } R\end{array}$ & $\begin{array}{c}\text { Pairwise } \\
\text { test } R\end{array}$ & $\begin{array}{c}\text { Significance } \\
\text { level (\%) }\end{array}$ \\
\hline Plants & 0.748 & & 0.1 \\
SA and SM & & 0.679 & 0.1 \\
SA and PA & & 0.790 & 0.1 \\
SM and PA & 0.830 & 0.852 & 0.1 \\
Sites & & 0.1 \\
$\begin{array}{l}\text { Dongtan and Jiuduansha } \\
\text { Dongtan and Nanhui }\end{array}$ & & 0.731 & 0.1 \\
Jiuduansha and Nanhui & & 0.915 & 0.1 \\
\hline
\end{tabular}

erally varied across sites and between seasons. Therefore, this study did not reveal an apparent difference in nematode taxon richness, diversity, or trophic composition between Spartina and Scirpus marshes.
Table 6. Results from BIO-ENV analysis of nematode communities (at the genus level and the functional group level) and environmental variables. The best combination of environment variables includes all variables marked with ' $y$ ' and the single best variable is indicated by ' $\mathrm{X}$ '. Correlation coefficients are given for the best combination of environmental variables and for the best single environmental variable

\begin{tabular}{|lcc|}
\hline & $\begin{array}{c}\text { Genus } \\
\text { level }\end{array}$ & $\begin{array}{c}\text { Functional } \\
\text { group level }\end{array}$ \\
\hline Combination & 0.165 & 0.242 \\
Single & 0.159 & 0.161 \\
Sand & & \\
Silt & & $\mathrm{y}$ \\
Clay & & \\
pH & $\mathrm{X}, \mathrm{y}$ & $\mathrm{X}, \mathrm{Y}$ \\
Water content & $\mathrm{y}$ & $\mathrm{Y}$ \\
Electrical conductivity & & \\
Organic matter & & $\mathrm{y}$ \\
Total nitrogen & & $\mathrm{y}$ \\
Total phosphorus & $\mathrm{y}$ & \\
Bacterial biomass & $\mathrm{y}$ & \\
Shoot biomass & & \\
Litter biomass & & \\
\hline
\end{tabular}



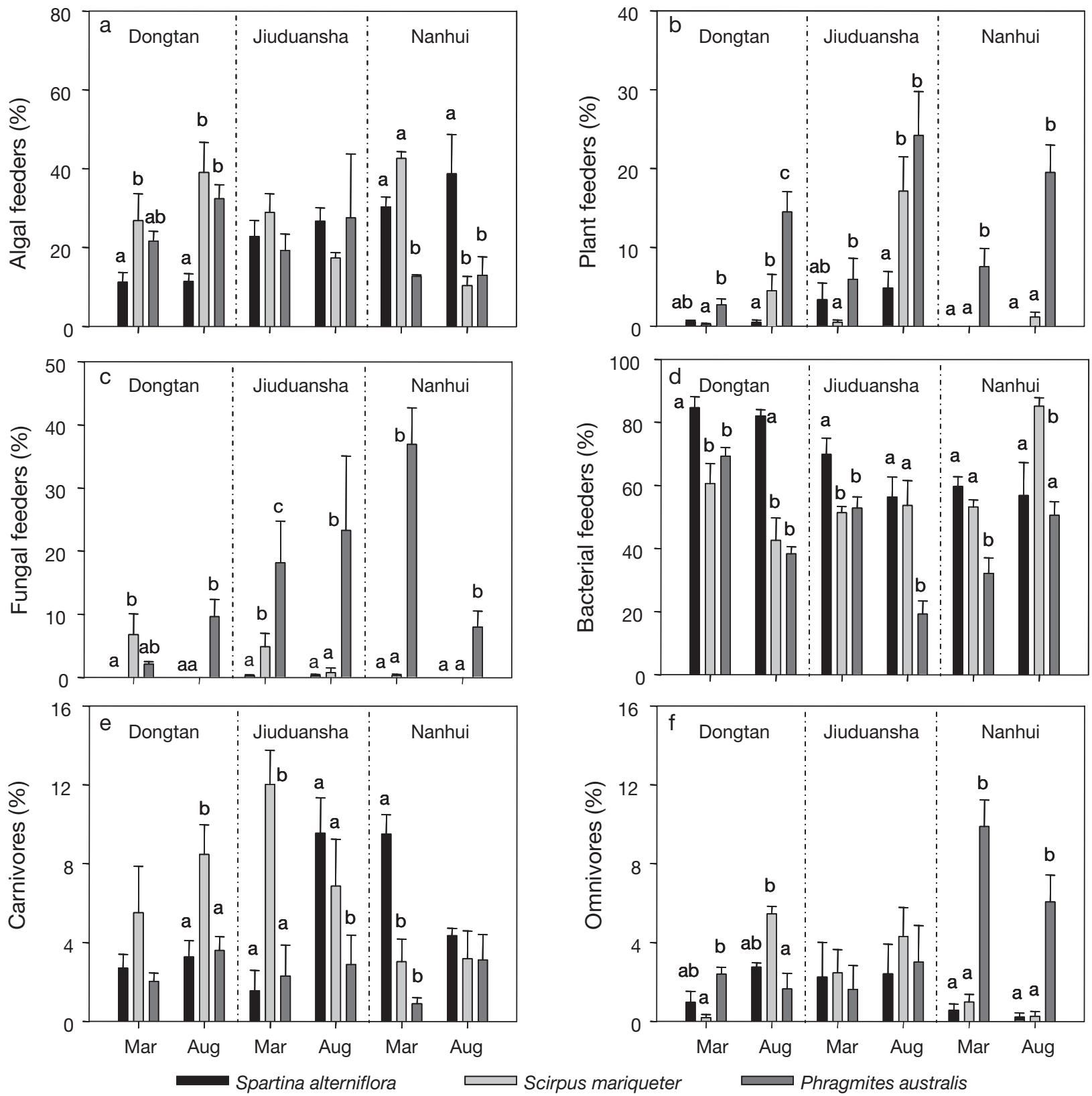

Fig. 3. Proportions of nematode feeding groups in the 3 marshes dominated, respectively, by Spartina alterniflora, Scirpus mariqueter, and Phragmites australis at 3 sites in March and August 2004: (a) algal feeders, (b) plant feeders, (c) fungal feeders, (d) bacterial feeders, (e) carnivores, and (f) omnivores. Error bars indicate standard error of the mean $(\mathrm{n}=4)$. Different letters above bars $(a, b, c)$ indicate significant differences between plant species at each sampling site and in each season $(p<0.05)$

Comparatively, the dissimilarity in the nematode community structure between Spartina and Phargmites marshes was greater than that between Spartina and Scirpus marshes, and the dissimilarity between Spartina-invaded and native marshes was even smaller than that between the 2 native plant marshes. In fact, the effects of Spartina invasions on nematode communities depended on which native plant species were considered. A similar result has been reported from a terrestrial system invaded by Bromus. Belnap \& Phillips (2001) found that the soil biota in plots from Hilaria to Bromus generally respond to the Bromus invasion in an opposite manner compared with plots from Stipa to Bromus. Therefore, it is important to consider native plants when the ecological consequences of plant invasions are assessed. 


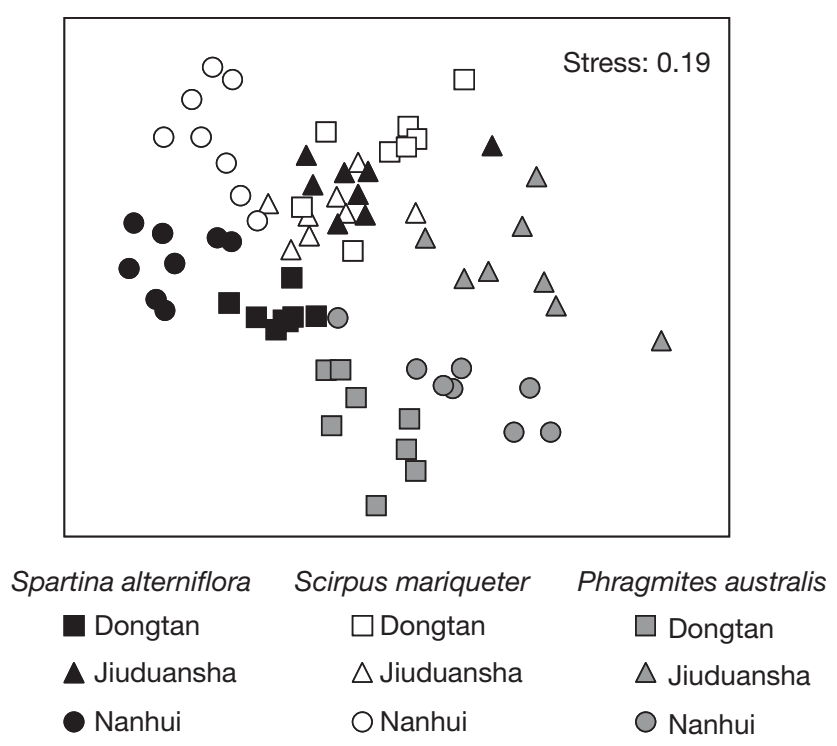

Fig. 4. Non-metric multidimensional scaling ordination of nematode communities in the 3 marshes dominated, respectively, by Spartina alterniflora, Scirpus mariqueter, and Phragmites australis at 3 sites. All replicate samples are included for analysis

\section{Effects of Spartina alterniflora invasions across sites}

Based on differences in morphology, physiology, and phenology, it has been documented that the replacement of extant marsh vegetation by exotic vascular plants may be expected to alter physical and chemical sediment properties (Talley \& Levin 2001). In the present study, the directions and magnitudes of the differences in sediment properties between Spartina and 2 native plant marshes were not consistent among different sites. Our data suggest that the impacts of Spartina invasion on sediment conditions in estuarine marshes of the Yangtze River are site specific and are driven by both plant invasion and natural environmental variation.

In the present study, the invasive Spartina generally had greater live shoot biomass than both Scirpus and Phragmites at all sites. Previous studies have indicated that, in the home regions of Spartina, the aboveground vegetation biomass of Spartina is smaller than that of Phragmites (Angradi et al. 2001, Osgood et al. 2003). The present study implies that the exotic plants grow better in the introduced range than in their natural range.

In terms of the impacts of invasive plants on animal communities, site effects have been documented previously. Hanson et al. (2002) found that Phragmites invasion impacts fishes in some habitats, but not others. Posey et al. (2003) demonstrated that the effect of macrophyte type is smaller than that of location in controlling macrofaunal distributions. Robertson \& Weis (2005) also found apparent between-site variations in their study. Yeates \& Williams (2001) investigated the influence of invasive weeds on nematode communities in New Zealand and pointed out that site is an important factor determining the impact of the invasive plant on nematodes. In this study, prominent site effects were also found in the relationship between nematodes and vegetation types, especially in the comparison of abundance, generic richness, diversity, and most feeding group proportions between Spartina and Scirpus marshes. However, patterns of nematode generic richness and diversity were generally similar between Spartina and Phragmites marshes at all the sites, and Spartina-invaded marshes had generally lower trophic diversity, a higher proportion of bacterial feeders, but a lower proportion of fungal feeders than Phragmites marshes. Therefore, the contribution of site effects varied with different extant plant species. Ravit et al. (2003) reported that the differences in microbial populations between plant species depend on the disturbance level of different sites. In this study, the nematode community dissimilarity among pairs of sites was the smallest between Dongtan and Jiuduansha. This is probably because Nanhui was more disturbed than the other sites. In addition to the disturbance level, the histories of plant invasion at different sites may also influence the site effects.

Although several studies have documented the roles of seasonality in the evaluation of invasive plant effects on fauna (Angradi et al. 2001, Talley \& Levin 2001, Osgood et al. 2003), our present study revealed that seasonal variation has less effect on nematode communities than sites and plant species.

\section{Underlying mechanisms and trophic implications}

There were significant physiological and morphological differences between Spartina and the 2 native plants, such as photosynthesis pathways $\left(\mathrm{C}_{4}\right.$ vs. $\left.\mathrm{C}_{3}\right)$ and salt tolerance (Spartina can excrete salts using its salt glands). The differences in these attributes are expected to change belowground biological communities and their composition (Wardle et al. 2004, Zedler \& Kercher 2004), including nematodes. However, the present study revealed that the dissimilarity in nematode community structure between $2 \mathrm{C}_{3}$ plants (Phragmites and Scirpus) was greater than that between $\mathrm{C}_{3}$ and $\mathrm{C}_{4}$ plants (native plants and Spartina). This suggests that the plant attributes, such as photosynthesis pathways, may not be as important as expected in structuring belowground communities. 
Two mechanisms have been proposed to explain how plant identity affects belowground biodiversity. First, different plant species may differ in their abilities to control resources available to organisms, through altering biotic and abiotic soil properties (Levin \& Talley 2000, Talley \& Levin 2001, Neira et al. 2005). Second, different plant species with different suites of traits may return organic matter of differing qualities or quantities to the soil (Díaz et al. 2004). In the present study, sediment water content, electrical conductivity, bacterial biomass, and litter biomass were identified as the most influential factors in shaping nematode communities, suggesting that both mechanisms might coexist in structuring nematode communities in the Yangtze River estuary. Wardle (2006) hypothesized that plant species drive soil organisms through litter production rather than through rhizosphere exudation. Although the rhizosphere characteristics were not investigated, our study did determine that litter production was more important than live plant biomass in affecting nematode communities. However, in the present study, the correlations between the environmental variables measured and the nematode communities were generally low at both the genus level and the functional group level. This suggests that other characteristics may also play important roles in structuring nematode communities.

In the current study, Spartina marshes had generally lower trophic diversity of nematodes than both Scirpus and Phragmites marshes, suggesting that the benthic food web became simpler after the invasion of Spartina. The relative abundance of bacterial-feeding nematodes tended to increase, but fungal feeders tended to decrease in Spartina compared with Phragmites communities. Since the abundance of different trophic groups of nematodes may reflect the presence of their food resource, the changes in the relative abundance of bacterial-feeding and fungal-feeding nematodes may be related to increased bacterial activity and suppressed fungal activity in Spartina marshes. These changes in Spartina marshes are likely to alter the decomposition processes, rates, and pathways, which may, in turn, modify belowground nutrient cycling of the estuarine wetlands. Ingham et al. (1985) found that bacterial-feeding nematodes can excrete $\mathrm{NH}_{4}{ }^{+} \mathrm{N}$, which may accelerate plant uptake and growth. Therefore, the trophic changes of nematodes may be expected to affect plant growth and the further expansion of invasive plants like Spartina.

Acknowledgements. The authors thank S. Tang, C. Liao, X. Cheng, and K. Jin for field sampling, and C. Song and $\mathrm{X}$. Wang for nematode sorting. This study was supported by NSFC funds (30570299 and 30370285), the Science and Technology Department of Shanghai (04QMX1405 and 04DZ19301), and the Ministry of Education (NCET-04-0360, 105063).

\section{LITERATURE CITED}

Angradi TR, Hagan SM, Able KW (2001) Vegetation type and the intertidal macroinvertebrate fauna of a brackish marsh: Phragmites vs. Spartina. Wetlands 21:75-92

Babiuk LA, Paul EA (1970) The use of fluorescein isothiocyanate in the determination of the bacterial biomass of a grassland soil. Can J Microbiol 16:57-62

Belnap J, Phillips SL (2001) Soil biota in an ungrazed grassland: response to annual grass (Bromus tectorum) invasion. Ecol Appl 11:1261-1275

Chen ZY, Li B, Chen JK (2004) Ecological consequences and management of Spartina spp. invasions in coastal ecosystems. Biodivers Sci 12:280-289

Chen ZY, Fu CZ, Wang HY, Li B, Wu JH, Chen JK (2005) Effects of Spartina alterniflora invasions on the benthic macroinvertebrate community at Dongtan of Chongming salt marsh, the Yangtze River estuary. Wetland Sci 3:1-7

Cheng XL, Luo YQ, Chen JQ, Lin GH, Chen JK, Li B (2006) Short-term $\mathrm{C}_{4}$ plant Spartina alterniflora invasions change the soil carbon in $\mathrm{C}_{3}$ plant-dominated tidal wetlands on a growing estuarine island. Soil Biol Biochem 38:3380-3386

Clark KR, Ainsworth M (1993) A method for linking multivariate community structure to environmental variables. Mar Ecol Prog Ser 92:205-209

Clarke KR, Warwick RM (1994) Change in marine communities: an approach to statistical analysis and interpretation. Plymouth Marine Laboratory, Plymouth

Cohen AN, Carlton JT (1998) Accelerating invasion rate in a highly invaded estuary. Science 279:555-558

Coleman DC (1985) Through a ped darkly: an ecological assessment of soil-root-microbial-faunal interactions. In: Fitter AH, Atkinson D, Read DJ, Usher MB (eds) Ecological interactions in soil. Blackwell, Oxford, p 1-21

Coull BC (1999) Role of meiofauna in estuarine soft-bottom habitats. Aust J Ecol 24:327-343

Díaz S, Hodgson JG, Thompson K, Cadibo M and 35 others (2004) The plant traits drive ecosystems: evidence from three continents. J Veg Sci 15:295-304

Gao ZG, Zhang LQ (2006) Identification of the spectral characteristics of saltmarsh vegetation using indirect ordination: a case study from Chongming Dongtan, Shanghai. J Plant Ecol 30:252-260

Gratton C, Denno RF (2005) Restoration of arthropod assemblages in a Spartina salt marsh following removal of the invasive plant Phragmites australis. Restor Ecol 13:358-372

Griffiths BS, Boag B, Neilson R, Palmer L (1990) The use of colloidal silica to extract nematodes from small samples of soil and sediment. Nematologica 36:465-473

Grosholz E (2002) Ecological and evolutionary consequences of coastal invasions. Trends Ecol Evol 17:22-27

Hanson SR, Osgood DT, Yozzo DJ (2002) Nekton use of a Phragmites australis marsh on the Hudson River, New York, USA. Wetlands 22:326-337

Hedge P, Kriwoken LK (2000) Evidence for effects of Spartina anglica invasion on benthic macrofauna in Little Swanport estuary, Tasmania. Aust Ecol 25:150-159

Ingham RE, Trofymow JA, Ingham ER, Coleman DC (1985) Interactions of bacteria, fungi, and their nematode grazers: effect on nutrient cycling and plant growth. Ecol Monogr 55:119-140

Jackson JBC, Kirby MX, Berger WH, Bjorndal KA and 15 others (2001) Historical overfishing and the recent collapse of coastal ecosystems. Science 293:629-638

Kriwoken LK, Hedge P (2000) Exotic species and estuaries: managing Spartina anglica in Tasmania, Australia. Ocean Coast Manage 43:573-584 
Levin LA, Talley T (2000) Influences of vegetation and abiotic environmental factors on salt marsh benthos. In: Weinstein MP, Kreeger DA (eds) Concepts and controversies in tidal marsh ecology. Kluwer Acedemic Publishers, Dordrecht, p 651-697

Levin L, Caswell H, Bridges T, DiBacco C, Cabrera D, Plaia G (1996) Demographic responses of estuarine polychaetes to pollutants: life table response experiments. Ecol Appl 6: 1295-1313

Levin LA, Bosch DF, Covich A, Dahm C and 8 others (2001) The function of marine critical transition zones and the importance of sediment biodiversity. Ecosystems 4:430-451

Levin LA, Neira C, Grosholz ED (2006) Invasive cordgrass modifies wetland trophic function. Ecology 87:419-432

Moore JC, de Ruiter PC (1991) Temporal and spatial heterogeneity of trophic interactions within below-ground food webs. Age Ecosyst Environ 34:371-397

Neira C, Levin LA, Grosholz ED (2005) Benthic macrofaunal communities of three sites in San Francisco Bay invaded by hydrid Spartina with comparison to uninvaded habitats. Mar Ecol Prog Ser 292:111-126

O'Connell KA (2002) Effects of invasive Atlantic smoothcordgrass (Spartina alterniflora) on infaunal macroinvertebrate communities in southern Willapa Bay, WA. MS thesis, Western Washington University, Bellingham, WA

Osgood DT, Yozzo DJ, Chambers RM, Jacobson D, Hoffman T, Wnek J (2003) Tidal hydrology and habitat utilization by resident nekton in Phragmites and non-Phragmites marshes. Estuaries 26:522-533

Posey MH (1988) Community changes associated with the spread of an introduced seagrass, Zostera japonica. Ecology 69:974-983

Posey MH, Wigand C, Stevenson JC (1993) Effects of an introduced aquatic plant, Hydrilla verticillata on benthic communities in the upper Chesapeake Bay. Estuar Coast Shelf Sci 37:539-555

Posey MH, Alphin TD, Meyer DL, Johnson JM (2003) Benthic communities of common reed Phragmites australis and marsh cordgrass Spartina alterniflora marshes in Chesapeake Bay. Mar Ecol Prog Ser 261:51-61

Ravit B, Ehrenfeld JG, Haggblom MM (2003) A comparison of sediment microbial communities associated with Phragmites australis and Spartina alterniflora in two brackish wetlands of New Jersey. Estuaries 26:465-474

Ritz K, Trudgill DL (1999) Utility of nematode community

Editorial responsibility: Lisa Levin (Contributing Editor),

La Jolla, California, USA analysis as an integrated measure of the functional state of soils: perspectives and challenges-discussion paper. Plant Soil 212:1-11

Robertson TL, Weis JS (2005) A comparison of epifaunal communities associated with the stems of salt marsh grasses Phragmites australis and Spartina alterniflora. Wetlands 25:1-7

Ruiz GM, Carlton JT, Grosholz ED, Hines AH (1997) Global invasions of marine and estuarine habitats by non-indigenous species: mechanisms, extent, and consequences. Am Zool 37:621-632

Talley TS, Levin LA (2001) Modification of sediments and macrofauna by an invasive marsh plant. Biol Invasions 3: 51-68

Wang Q, An SQ, Ma ZJ, Chen JK, Li B (2006) Invasive Spartina alterniflora: biology, ecology and management. Acta Phytotaxono Sin 44:559-588

Wardle DA (2006) The influence of biotic interactions on soil biodiversity. Ecol Lett 9:870-886

Wardle DA, Bardgett RD, Klironomos JN, Setala H, van der Putten WH, Wall DH (2004) Ecological linkages between aboveground and belowground biota. Science 304: 1629-1633

Wu J, Fu C, Chen S, Chen J (2002) Soil faunal response to land use: effect of estuarine tideland reclamation on nematode communities. Appl Soil Ecol 21:131-147

Yeates GW (1999) Effects of plants on nematode community structure. Annu Rev Phytopathol 37:127-149

Yeates GW, Williams PA (2001) Influence of three invasive weeds and site factors on soil microfauna in New Zealand. Pedobiologia 45:367-383

Yeates GW, Bongers T, De Goede RGM, Freckman DW, Georgieva SS (1993) Feeding habitats in soil nematode families and genera-an outline for soil ecologists. J Nematol 25:315-331

Yuhas CE, Hartman JM, Weis JS (2005) Benthic communities in Spartina alterniflora- and Phragmites australis-dominated salt marshes in the Hackensack meadowlands, New Jersey. Urban Habitats 3:158-191

Zedler JB, Kercher S (2004) Causes and consequences of invasive plants in wetlands: opportunities, opportunists, and outcomes. Crit Rev Plant Sci 23:431-452

Zipperer VT (1996) Ecological effects of the introduced cordgrass, Spartina alterniflore, on the benthic community structure of Willaps Bay, Washington. MS thesis, University of Washington, Seattle, WA

Submitted: February 27, 2006; Accepted: September 21, 2006 Proofs received from author(s): April 10, 2007 